\title{
Implementasi PRNG Menggunakan Karakter Nama Pada Pembangkitan Kunci RSA
}

\author{
Mufidah Khairani ${ }^{1}$ \\ Program Studi Teknik Informatika, STT-Harapan \\ mufida.khairani@gmail.com
}

\begin{abstract}
Abstrak
Implementasi RSA membutuhkan dua bilangan prima yang memenuhi kondisi - kondisi tertentu sehingga menyulitkan dalam proses pembangkitan kunci yang mana beberapa implementasi lebih memilih menggunakan bilangan prima secara acak sehingga tidak ada kaitan sama sekali antara pengguna dan kunci yang dimilikinya. Pembangkitan kunci pada kriptografi RSA dengan mengikutsertakan identitas pemilik seperti nama dapat dilakukan dengan menggunakan metode pembangkit bilangan acak semu atau yang biasa sering disebut dengan Pseudo Random Number Generator. Salah satu metode pembangkit bilangan acak semu yang cukup terkenal yaitu LCG. Implementasi LCG digunakan untuk membangkitkan bilangan acak semu yang digunakan dalam pembangkitan kunci pada algoritma RSA. Dengan menggunakan LCG maka identitas pemilik berpengaruh terhadap kunci publik maupun kunci private dari si pemilik. Implementasi menunjukkan tingkat keunikan kunci yang dibangkitkan cukup baik dan dapat dibangkitkan berulang - ulang sesuai dengan identitas dari pemilik kunci tersebut dibandingkan dengan pembangkitan acak total yang mana kunci yang dibangkitkan berikutnya belum tentu sama dengan kunci sebelumnya. Implementasi LCG masih membutuhkan mekanisme tambahan mengingat pengguna dengan nama yang sama memungkinkan pembangkitan kunci yang sama.

Kata Kunci : Kriptografi, RSA, Public Key, PRNG, $L C G$
\end{abstract}

\section{Pendahuluan}

Kriptografi merupakan salah satu komponen yang tidak dapat diabaikan dalam membangun keamanan komputer. Kriftografi merupakan suatu ilmu dan seni (science and art) dalam penyandian data, yang bertujuan untuk menjaga kerahasiaan dan keamanan data dari serangan ataupun diketahui diketahui oleh pihak yang tidak berhak. Kriptografi menggunakan matematika aljabar, terutama teori bilangan sebagai dasar pengetahuan. Kriptografi juga mengandung seni karena dalam aplikasinya mengandung pola-pola tertentu yang digunakan sebagai sandi [1].

Kriptografi merupakan studi matematis yang terkait dengan aspek-aspek yang berhubungan dengan keamanan informasi seperti menyembunyikan isi data, mencegah data dapat dirubah tanpa terdeteksi, ataupun mencegah data digunakan tanpa otoritas yang cukup. Kriptografi dilakukan untuk menyembunyikan konten dari suatu informasi dengan mengubah informasi tersebut menjadi sandi dengan menggunakan kunci, dan untuk membacanya diperlukan kunci pula. Berdasarkan kerahasiaan kuncinya algoritma kriptografi dapat dibedakan menjadi algoritma sandi kunci (private key) dan algoritma sandi kunci publik (public key). Salah satu algoritma kunci publik (public key) yang sering digunakan adalah algoritma Rivert-Shamir-Adleman (RSA)[2].

Penelitian mengenai implementasi algoritma RSA telah banyak dilakukan seperti yang dilakukan oleh Hamzah [3] dan Fresly [4]. Implementasi RSA membutuhkan dua bilangan prima yang memenuhi kondisi - kondisi tertentu sehingga menyulitkan dalam proses pembangkitan kunci yang mana beberapa implementasi lebih memilih menggunakan bilangan prima secara acak sehingga tidak ada kaitan sama sekali antara pengguna dan kunci yang dimilikinya.

Pada penelitian ini akan dianalisis pembangkitan kunci pada kriptografi RSA dengan mengikutsertakan identitas pemilik seperti nama menggunakan metode pembangkit bilangan acak semu atau yang biasa sering disebut dengan Pseudo Random Number Generator. Salah satu metode pembangkit bilangan acak semu yang cukup terkenal yaitu LCG. LCG atau Linear Congruential Generator merupakan metode pembangkit bilangan acak semu yang menghasilkan bilangan acak yang memiliki periode dan sangat ditentukan oleh parameter input sehingga bilangan yang dibangkitkan tidak sepenuhnya acak [5].

Implementasi LCG pada penelitian ini digunakan untuk membangkitkan bilangan acak semu yang digunakan dalam pembangkitan kunci pada algoritma RSA. Dengan menggunakan LCG maka identitas pemilik berpengaruh terhadap kunci publik maupun kunci private dari si pemilik sehingga 
kunci tetap dapat dibangkitkan kembali jika mengalami kehilangan atau kelupaan.

\section{RSA}

Penemu pertama algoritma kriptografi kunci asimetri adalah Clifford Cocks, James H. Ellis dan Malcolm Williamson (sekelompok ahli matematika yang bekerja untuk United Kindom's Government Communication Head Quarters, agen rahasia Inggris) pada awal tahun 1970. Pada waktu itu temuan itu dipublikasikan dan fakta mengenai temuan tersebut menjadi rahasia hingga tahun 1997. Algoritma kriptografi kunci asimetri untuk pertama kalinya dipublikasikan pada tahun 1976 oleh Whitfirld Diffie dan Martin Hellman. Dua orang tersebut merupakan ilmuwan dari Stanford University, yang membahas metode pendistribusian kunci rahasia melalui saluran komunikasi umum (public), yang kemudian metode tersebut dikenal dengan metode pertukaran kunci Diffie-Hellman (Diffie-Hellman Key Exchange).

Ide awal Clifford Cocks ditemukan kembali oleh sekelompok ilmuwan dari Massachussets Institute of Technology pada tahun 1977, sekelompok orang ini adalah Ron Rivest, Adi Shamir, dan Leonard Adleman. Mereka kemudian mempublikasikan temuan mereka pada tahun 1978 dan algoritma kriptografi kunci asimetri yang mereka temukan dikenal dengan nama algoritma kriptografi RSA. RSA itu sendiri merupakan akronim dari nama keluarga mereka, Rivest, Shamir, dan Adleman. Pada tahun 1983, Massachussets Institute of Technology menerima hak paten atas sebuah makalah berjudul "Cryptography Communication System and Method" yang mengaplikasikan penggunaan algoritma kriptografi RSA [6].

RSA merupakan algoritma enkripsi yang termasuk jenis asimetris. Proses enkripsi dan dekripsi dari algortima RSA menggunakan key yang berbeda. Proses enkripsi menggunakan sebuah public key sedangkan pada proses dekripsi dibutuhkan sebuah private key. Kriptografi public key yang paling banyak digunakan ialah RSA. Tingkat kesulitan untuk menyerang enkripsi RSA bergantung pada sulitnya pencarian faktor bilangan prima yang digunakan untuk enkripsi ini [7].

Keamanan algoritma RSA terletak pada sulitnya memfaktorkan bilangan yang besar menjadi faktorfaktor prima. Pemfaktoran dilakukan untuk memperoleh kunci pribadi. Selama pemfaktoran bilangan besar menjadi faktor-faktor prima belum ditemukan algoritma yang mangkus, maka selama itu pula keamanan algoritma RSA tetap terjamin. Algoritma enkripsi/dekripsi RSA dilakukan sebagai berikut [8]:

Ee $(\mathrm{m})=\mathrm{c}=\operatorname{me} \bmod \mathrm{n}$, dan

$\operatorname{Dd}(\mathrm{c})=\mathrm{m}=\mathrm{cd} \bmod \mathrm{n}$, dimana Ee (m) merupakan fungsi enkripsi terhadap plaintext $\mathrm{m}$, Dan D d (c) merupakan fungsi dekripsi terhadap chipertext $\mathrm{c}$. Nilai d, e, $\mathrm{n}$ itu sendiri merupakan pasangan kunci publik $(\mathrm{e}, \mathrm{n})$ dan kunci privatnya (d) yang diperoleh dengan menggunakan aturan pembangkitan kunci sebagai berikut:

1. Pilih dua buah bilangan prima sembarang, $p$ dan q.

2. Hitung $\mathrm{n}=\mathrm{p} . \mathrm{q}$ (sebaiknya $\mathrm{p} \neq \mathrm{q}$, sebab jika $\mathrm{p}=\mathrm{q}$ maka $\mathrm{n}=\mathrm{p} 2$ sehingga $\mathrm{p}$ dapat diperoleh dengan mudah dengan menarik akar pangkat dua dari $n)$.

3. Hitung $\phi(n)=(p-1)(q-1)$.

4. Pilih kunci publik e, yang relatif prima terhadap $\phi(n)$.

5. Bangkitkan kunci privat dengan menggunakan persamaan e.d $\equiv 1(\bmod \phi(n))$ yang ekivalen dengan e.d $=1+k \phi(n)$,

\section{PRNG LCG}

Linear Congruential Generator merupakan pembangkit bilangan acak semu yang didasarkan pada kemunculan linear [5]. Kelebihan utama dari linear congruential generator adalah kecepatan yang tinggi dan memiliki property statistic yang baik berdasarkan pemilihan parameter $a, b, M$. Persamaan untuk membangkitkan bilangan acak menggunakan linear congruential generator adalah sebagai berikut.

Dimana :

$$
X_{n+1}=a X_{n}+b \bmod M
$$

$a, b$, dan $M=$ Parameter yang dipilih secara acak dan bersifat tetap.

$X_{n+1}=$ Bilangan acak ke- $\mathrm{n}+1$

$X_{n}=$ Bilangan acak ke-n.

\section{Implementasi PRNG LCG Pada Pembangkitan Kunci RSA}

Implementasi PRNG LCG pada pembangkitan kunci RSA dilakukan dengan menggunakan nama pengguna sebagai input agar kunci yang dibangkitkan dapat merepresentasikan identitas dari pengguna serta dapat di bangkitkan kembali dengan mudah kapan saja dibutuhkan. Secara umum peran dari PRNG LCG adalah memberikan atau menyediakan nilai - nilai yang memenuhi kriteria $p$ dan $q$ pada proses pembangkitan kunci pada algoritma RSA. Nilai - nilai $p$ dan $q$ tersebut diperoleh dari nilai - nilai acak yang dibangkitkan dari PRNG LCG dengan menggunakan nilai ASCII dari karakter nama pengguna.

Secara umum tahapan implementasi PRNG LCG pada pembangkitan kunci pada algoritma RSA dapat dijabarkan sebagai berikut :

1. Menerima input identitas nama pengguna dan mengkonversikannya menjadi kode ASCII. 
2. Nilai ASCII yang terbesar akan menjadi variabel $M$ pada pembangkitan PRNG LCG.

3. Variabel $a$ diambil dari nilai ASCII karakter pertama dan variabel $b$ diambil dari karakter kedua dari karakter identitas nama pengguna.

4. Nilai acak awal $X(0)$ diambil dari nilai ASCII terkecil dari karakter nama pengguna.

5. Membangkitkan bilangan acak PRNG LCG sebanyak $n$.

6. Memilih dua nilai bilangan acak pertama yang merupakan bilangan prima dan melanjutkannya ke proses pembangkitan kunci RSA.

7. Jika tidak ditemukan dua nilai bilangan acak prima maka proses pembangkitan PRNG LCG diulang dengan menggunakan nilai variabel $a$ dan variabel $b$ dari karakter - karakter berikutnya.

8. Jika semua karakter telah digunakan dan tetap tidak dapat ditemukan nilai bilangan acak yang prima, maka proses dihentikan dan nama tidak dapat digunakan pada proses pembangkitan PRNG LCG.

Sebagai contoh di asumsikan pengguna memberikan nama "Mufidah" sebagai input maka proses pembangkitan kunci pada RSA adalah sebagai berikut:

1. Mengkonversi karakter nama ke nilai ASCII sehinggai diperoleh nilai ASCII :
(M) 77
(u) $\quad 117$
(f) 102
(i) $\quad 105$
(d) $\quad 100$
(a) $\quad 97$
(h) $\quad 104$

2. Mengambil nilai ASCII terbesar menjadi nilai $\mathrm{M}$.

$\mathrm{M}=117$

3. Variabel $a$ dan variabel $b$ diperoleh dari karakter pertama dan kedua.

$\mathrm{a}=77$

$\mathrm{b}=117$

4. Nilai $X(0)$ menggunakan nilai ASCII terkecil.

$\mathrm{X}(0)=77$

5. Membangkitkan PNRG LCG sebanyak n :
(8) $\quad 116$
(9) 40

6. Memilih dua buah bilangan primayang berbeda. Dikarenakan hanya satu jenis bilangan prima yang ditemukan maka proses pembangkitan diulang menggunakan variabel $a$ dan $b$ yang baru dari karakter nama berikut nya sehingga diperoleh PNRG LCG sebagai berikut :

$a=105$

$b=100$

\begin{tabular}{|l|l|l|}
\hline $\mathrm{I}$ & $\mathrm{X}(\mathrm{i})$ & Prima \\
\hline 0 & 77 & No \\
\hline 1 & 112 & No \\
\hline 2 & 43 & Yes \\
\hline 3 & 52 & No \\
\hline 4 & 61 & Yes \\
\hline 5 & 70 & No \\
\hline 6 & 79 & Yes \\
\hline 7 & 88 & No \\
\hline 8 & 97 & Yes \\
\hline 9 & 106 & No \\
\hline
\end{tabular}

7. Dari pembangkitan PNRG LCG diatas diperoleh dua bilangan prima berbeda yaitu 43 dan 61.

8. Kedua bilangan prima tersebut kemudian akan digunakan sebagai variabel $p$ dan $q$ pada proses pembangkitan kunci RSA sehingga menghasilkan kunci publik dan kunci private yaitu :

2291-2623 dan 11-2623

\section{Pembahasan Hasil Implementasi PNRG LCG Pada Pembangkitan Kunci RSA}

Hasil implementasi menunjukkan bahwa implementasi PNRG LCG dapat digunakan untuk membantu membangkitkan kunci pada algoritma RSA. Pada beberapa percobaan yang dilakukan hampir semua nama dapat digunakan dalam pembangkitan kunci RSA, berikut beberapa percobaan terhadap nama yang berbeda :

$\begin{array}{lll}\text { (0) } & 77 & \\ (1) & 79 & \text { Prima } \\ (2) & 116 & \\ (3) & 40 & \\ (4) & 38 & \\ (5) & 1 & \\ (6) & 77 & \\ (7) & 79 & \text { Prima }\end{array}$


Tabel 2 Pengujian Pembangkitan Kunci

\begin{tabular}{|l|l|l|}
\hline No. & Nama & Kunci \\
\hline 1 & Mufidah & $2291-2623$ \\
& & $11-2623$ \\
\hline 2 & Khairunnisa & $2091-3277$ \\
& & $3-3277$ \\
\hline 3 & Azzizzi & $29-219$ \\
& & $5-219$ \\
\hline 4 & Azzahra & $29-219$ \\
& & $5-219$ \\
\hline 5 & Khaidir & $2091-3277$ \\
& & $3-3277$ \\
\hline 6 & Julham & $1783-3233$ \\
& & $7-3233$ \\
\hline 7 & Zulpahmi & $245-1339$ \\
& & $5-1339$ \\
\hline
\end{tabular}

Berdasarkan pengujian yang dilakukan seperti yang terlihat pada tabel 2, dapat dilihat kunci yang dibangkitkan berbeda - beda antara nama yang satu dengan nama yang lain, namun ditemukan dua nama yang berbeda yang memiliki nama yang sama yang mana disebabkan oleh pengambilan nilai $a$ dan $b$ yang sama dari kedua nama tersebut.

\section{Kesimpulan}

Berdasarkan penelitian yang telah dilakukan dapat disimpulkan bahwa penggunaan PNRG LCG dapat membantu dalam membangkitkan kunci pada algoritma RSA yang mana kunci tersebut dapat merepresentasikan identitas dari pemilik serta dapat dibangkitkan ulang sesuai dengan identitas nama pemilik kunci. Kunci yang dibangkitkan memiliki kemungkinan terjadinya kesamaan antara pengguna satu dengan pengguna lainnya yang memiliki karakter nama yang hampir sama, untuk itu varian varian metode dapat di tambahkan untuk melengkapi implementasi yang dilakukan pada penelitian ini.

\section{References}

[1] Novi, 2011, Penerapan Teknik kriptografi StreamChiper Untuk Pengaman Basis Data, Juornal ISSN: 1978-9483 Volume 6, No.1. Universitas Nasional Jakarta Selatan.

[2] Munawar, 2012, Perancangan Algoritma Sistem Keamanan Data Menggunakan Metode Kriptografi Asimetris, Juornal Volume 1, No.1, Bandung.

[3] Hamzah, 2012, Implementasi Algoritma RSA Dan Blowfish Untuk Enkripsi Dan Dekripsi Data Menggunakan Delphi 7, Juornal ISSN: 2723-9101 Volume 4, No.1, UIN-Jakarta.

[4] Fresly, 2015, Implementasi Kriptografi Pengamanan Data Pada Pesan Teks, Isi File Dokumen Menggunakan Algoritma Advance Encryption Standard. Juornal Volume 10, No.1. Universitas Mulawarman.

[5] Lirkov, I., \& Stoilova, S. (2010). Analysis of Pseudo-Random Properties of Nonlinear
Congruential Generators with Power of Two Modulus by Numerical Computing of the b-adic Diaphony. Proceedings of the International Multiconference on Computer Science and Information Technology pp. 309-315.

[6] Reza Arya, 2013, Penyembunyian Pesan Rahasia yang Terenkripsi Menggunakan Algoritma RSA Pada Media Kompresi, Juornal ISSN: 2337-3539 Vol. 2 No.1, ITS-Surabaya.

[7] Wahyuni Ana, 2011, Keamanan Pertukaran Kunci Kriptografi dengan Algoritma Hybrid DiffieHellman dan RSA, Juornal Volume 2, No.2, Universitas AKI.

[8] Rosnawan Dadan, 2011, Aplikasi Algoritma RSA Untuk Keamanan Data Pada Sistem Informasi Berbasis WEB, Universitas Negeri Semarang. 